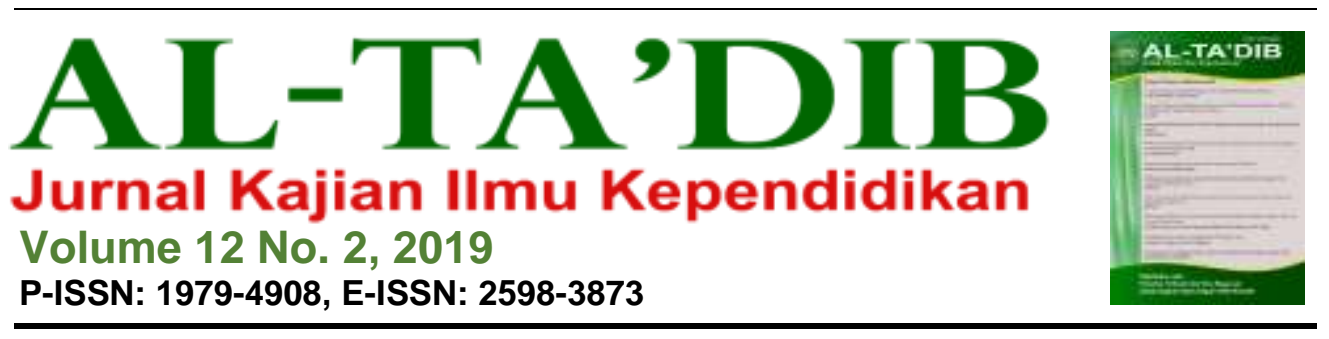

\title{
Metode Keteladanan dalam Pendidikan Islam terhadap Anak di Pondok Pesantren
}

\author{
Ahmad Aly Syukron Aziz Al Mubarok ${ }^{1}$ \\ ${ }^{1}$ Institut Agama Islam Uluwiyah Mojokerto, Mojokerto, Indonesia. E-mail: syukron99@gmail.com
}

\begin{tabular}{l} 
INFORMASI ARTIKEL \\
\hline Kata Kunci: \\
Anak; keteladanan; \\
pendidikan Islam; \\
pesantren \\
Cara Mensitasi: \\
Al Mubarok, A. A. S. A. \\
(2019). Metode \\
Keteladanan dalam \\
Pendidikan Islam terhadap \\
Anak di Pondok Pesantren. \\
Al-Tadib: Jurnal Kajian \\
Ilmu Kependidikan, 12(2), \\
306-321. \\
DOI: \\
http://dx.doi.org/10.31332/ \\
atdbwv12i2.1447 \\
\hline
\end{tabular}

\begin{abstract}
ABSTRAK
Penelitian kualitatif ini dilakukan untuk mendeskripsikan dan menggambarkan bahwa keteladanan terhadap anak di pondok pesantren dapat menjadi contoh pendidikan Islam serta keberhasilan dalam mempersiapkan dan membentuk aspek moral, spiritual dan sosial anak. Fokus pada keseharian di salah satu pondok pesantren, penelitian ini menemukan bahwa untuk melihat keteladanan terhadap anak, pendidik menjadi contoh terbaik karena mereka yang akan ditirunya dalam tindak-tunduknya, tata santunnya baik disadari maupun tidak. Jika keteladanan telah tertanam maka akan tercetak dalam jiwa dan perasaan anak didik gambaran pendidik baik dalam ucapan maupun perbuatan, baik material maupun spiritual.
\end{abstract}




\begin{tabular}{l} 
ARTICLE INFO \\
\hline Keywords: \\
Children; exemplary; \\
Islamic education; \\
modeling \\
How to cite: \\
Al Mubarok, A. A. S. A. \\
(2019). Metode \\
Keteladanan dalam \\
Pendidikan Islam terhadap \\
Anak di Pondok Pesantren. \\
Al-Tadib: Jurnal Kajian \\
Ilmu Kependidikan, 12(2), \\
306-321. \\
DOI: \\
http://dx.doi.org/10.31332/ \\
atdbwv12i2.1447 \\
\hline
\end{tabular}

\begin{abstract}
This qualitative research was conducted to describe and illustrate that exemplary deeds in Islamic education could be of model for children and the success in preparing and shaping their moral, spiritual and social aspects. Focusing on daily routines at an Islamic boarding school (pesantren), this research found that in order to teach exemplary deeds to the children, the teachers should be the best model for them because their tendency to imitate the adults in their submissiveness. When the good deeds are ingrained in their soul and feeling, the exemplary teacher will color their words and deeds.
\end{abstract}

\section{Pendahuluan}

Pendidikan Islam pada dasarnya merupakan upaya pembinaan dan pengembangan potensi manusia, agar tujuan kehadirannya di dunia ini sebagai hamba Allah dan sekaligus tugas khalifah Allah tercapai sebaik mungkin. Potensi yang dimaksud meliputi potensi jasmaniah dan potensi rohaniah seperti akal, perasaan, kehendak, dan potensi rohani lainnya (Mappasiara, 2018). Pendidikan Islam mempunyai tujuan yang luas dan dalam, seluas dan sedalam kebutuhan hidup manusia sebagai makhluk individu dan sebagai makhluk sosial yang menghamba kepada Khaliknya dengan dijiwai oleh nilainilai ajaran agama (Musrifah, 2017).

Pendidikan Islam dalam keluarga merupakan proses pembentukan kepribadian Islam pada anak. Diperlukan peran dan tanggung jawab orang tua sebagai pendidik utama dalam mendidik anak dengan baik. Dari sinilah masalah keteladanan menjadi faktor penting dalam hal baik-buruknya anak. Fitrah, dalam pandangan 'Ulwan diterjemahkan sebagai pemikiran yang mendefinisikan bahwa manusia memiliki kecenderungan kebaikan dan keburukan bawaan. Oleh karenanya, anak usia dini membutuhkan bentuk pengkondisian untuk mengembangkan kepribadian peserta didik melalui tiga pendekatan, yaitu metode pendidikan anak yang sesuai, pembentukan kesiapan pendidik dan keterikatannya dengan anak, dan pengkondisian lingkungan pendidikan anak usia dini (Purnama, 2018).

Dalam pendidikan, seorang pendidik mungkin dapat menemukan suatu sistem dengan mempertimbangkan berbagai hal yang terkait dalam proses 
pendidikan dengan harapan agar tujuan pendidikan berhasil secara maksimal. Namun, semua ini masih memerlukan realisasi edukatif yang dilaksanakan oleh seorang pendidik. Pelaksanaannya itu memerlukan seperangkat metode dan tindakan dalam rangka mewujudkan tujuan itu. Ini semua hendaknya ditata dalam sistem pendidikan yang menyeluruh dan terbaca dalam perencanaan serta dapat diterapkan dalam perilaku yang kongkrit (Hidayat, 2015). Kehidupan seorang manusia tidak jauh berbeda dengan kehidupan manusia lainnya. Sifat-sifat yang ada pada manusia cenderung ada suatu kesamaan. Hal ini bisa diketahui jika seseorang berbuat sesuatu karena terobsesi oleh perbuatan orang lain. Wajar bila sifat-sifat yang ada pada manusia memiliki kecenderungan untuk meniru.

Pendidikan Islam adalah usaha orang dewasa muslim yang bertakwa secara sadar mengarahkan dan membimbing pertumbuhan serta perkembangan fitrah (kemampuan dasar) anak didik melalui ajaran Islam ke arah titik maksimal pertumbuhan dan perkembangannya (Akaha, 2001). Dalam pendidikan Islam terdapat banyak dimensi. Dimensi itu antara lain menyangkut persoalan pendidik, peserta didik, kurikulum, metodologi, dan termasuk pula lembaga penyelenggara pendidikan. Dimensi-dimensi ini dalam dunia pendidikan mutakhir sering dipersoalkan orang di masyarakat, dengan alasan kurang serius dalam menanggani kegiatan pendidikan khususnya pendidikan Islam yang berkaitan erat dengan transformasi nilainilai spiritual dan kemanusiaan, sehingga berdampak pada dekadensi moralitas dan akhlak bangsa (Yasin, 2008).

Dekadensi moral dan akhlak bangsa bisa juga dipengaruhi media massa yang akan berdampak negatif jika digunakan ke arah penyimpangan dan kerusakan, seperti menyebarkan berita yang tidak benar, mempengaruhi anakanak pada prinsip-prinsip selain Islam, menampilkan perbuatan yang tidak baik, dan nasihat-nasihat yang menyesatkan. Selama penggunaannya seperti itu, maka media masssa menjadi alat perusak generasi muslim (Juliadarma, 2013). Padahal tujuan pendidikan Islam mengandung nilai-nilai tertentu sesuai dengan pandangan Islam sendiri yang harus direalisasikan melalui proses yang terarah dan konsisten dengan menggunakan berbagai sarana fisik dan nonfisik yang sama dengan nilai-nilainya. Islam merupakan syariat Allah bagi manusia. Dengan bekal syariat itu manusia beribadah. Agar manusia mampu memikul dan merealisasikan amanah besar itu, syariat itu membutuhkan pengamalan, pengembangan, dan pembinaan. Pengembangan dan pembinaan itulah yang dimaksud dengan pendidikan Islam (Haris, 2010).

Harapan besar orang tua kepada anaknya menunjukkan rasa sayangnya kepada sang buah hati. Harapan besar ini tentu tidak akan bisa datang dengan sendirinya, melainkan harus diimbangi dengan memberikan pendidikan yang baik dengan disertai keteladanan (At-Tarbiyah bi Al-Uswah Al-hasanah). Sesungguhnya seorang anak, betapapun potensinya untuk kebaikan itu besar, 
dan betapapun fitrahnya itu suci bersih, dia tak akan bisa melaksanakan prinsip-prinsip kebaikan dan pokok-pokok pendidikan yang baik, apabila dia tidak melihat pendidik mereka ada di puncak keutamaan akhlak. Bahkan setiap kebaikan akan diterima menjadi salah satu kebiasaan dan kesenangan, dan kemuliaan akan menjadi akhlak dan sifat yang paling utama (Arisanti, 2017). Anak dapat dipandang sebagai individu yang baru mengenal dunia. Anak belum mengetahui tata krama, norma, etika dan berbagai hal tentang dunia. Anak juga sedang belajar berkomunikasi dengan orang lain dan belajar juga dalam memahami orang lain. Anak perlu dibimbing agar mampu memahami berbagai hal tentang dunia dan isinya. Ia juga perlu dibimbing agar memamhami berbagai fenomena alam agar dapat melakukan keterampilanketerampilan yang dibutuhkan untuk hidup di masyarakat (Aryani, 2015). Oleh karena itu, seorang pendidik dapat mendikte anak melalui sebuah sistem dari pembinaan, akan tetapi sulit bagi anak itu untuk melaksanakan sistem ini ketika dia melihat bahwa orang yang mendidiknya dan mengarahkannya tidak konsekuen dengan sistem ini serta tidak mengaplikasikan pokok-pokok dan prinsip-prinsip yang ditanamkan.

Adapun dasar-dasar dari pendidikan Islam adalah Al-Qur'an dan AsSunnah. Pertama, Al-Qur'an yang berarti bacaan, yang merupakan kata turunan (masdar) dari fiil madhi qara'a dengan arti ism al-maful yaitu maqru' yang artinya dibaca seperti yang termaktub di dalam Q.S. Al-Alaq ayat 1-5 "Bacalah dengan (menyebut) Nama Tuhanmu Yang menciptakan, Dia telah menciptakan manusia dari segumpal darah. Bacalah, dan Tuhanmu lah Yang Maha Pemurah, Yang mengajar (manusia) dengan perantaraan kalam, Dia mengajar kepada manusia apa yang tidak diketahuinya." Kedua, As-Sunnah menjadi dasar dalam pendidikan Islam yang merupakan perkataan, perbuatan apapun pengakuan Rasulullah SAW. Pengakuan yang dimaksud adalah perbuatan orang lain yang diketahui oleh Rasulullah dan beliau membiarkan saja kejadian itu berjalan. Sunnah merupakan sumber ajaran kedua yang juga berisi tentang akidah, syari'ah, dan tentang pedoman untuk kemaslahatan hidup manusia seutuhnya (Daradjat, 2006).

Tujuan pendidikan Islam berdasarkan peranan manusia sebagai hamba Allah (Achmadi, 2005) ada beerapa. Pertama, tujuan manusia adalah menjadi hamba Allah yang bertakwa. Tujuan ini sejalan dengan tujuan hidup dan penciptaan manusia, yaitu semata-mata untuk beribadah kepada Allah. Dengan pengertian ibadah yang demikian itu maka implikasinya dalam pendidikan terbagi atas dua macam, yaitu: a) pendidikan memungkinkan manusia mengerti tuhannya secara benar sehingga semua perbuatan terbingkai ibadah yang penuh dengan penghayatan kepada keEsaan-Nya, dan, b) pendidikan harus menggerakkan seluruh potensi manusia untuk memahami 
sunnah Allah diatas bumi. Kedua, tujuan manusia sebagai pendidik adalah mengantarkan subjek didik menjadi khalifatullah fil ard (wakil Tuhan diatas bumi) yang mampu memakmurkannya. Ketiga, tujuan manusia terdidik adalah memperoleh kesejahteraan serta kebahagiaan hidup di dunia sampai akhirat.

Menurut Omar Muhammad al-Taumy al-Syaibani (1979/2007), tujuan pendidikan Islam ada pada tiga bidang dasar. Pertama, tujuan individual yang berkaitan dengan pelajaran (learning), pribadi, tingkah laku, aktivitas, dan pencapaiannya, pertumbuhan yang diinginkan, serta persiapan untuk kehidupan dunia dan akhirat. Kedua, tujuan sosial yang berkaitan dengan kehidupan masyarakat secara keseluruhan dengan tingkah laku masyarakat umumnya, berkaitan dengan kehidupan, memperkaya pengalaman dan kemajuan yang diingini. Ketiga, tujuan profesional yang berkaitan dengan pendidikan dan pengajaran sebagai ilmu, seni, profesi dan suatu aktivitas diantara aktivitas-aktivitas masyarakat.

Lain halnya dari beberapa definisi di atas, Ki Hajar Dewantara dalam Yus (2011), menyatakan bahwa pendidikan adalah ing ngarso sungtulodo, ing madyo mangunkarso, tut wuri handayani. Pendidikan dilaksanakan dengan memberi contoh teladan, memberi semangat, dan mendorong anak untuk berkembang. Sistem yang dipakai ialah sistem "among" dengan maksud memberi kemerdekaan, kesukarelaan, demokrasi, toleransi, ketertiban, kedamaian, kesesuaian dengan keadaan, dan hindari perintah dan paksaan. Sistem ini mendidik anak menjadi manusia yang merdeka batinnya, pikirannya, dan tenaganya, serta dapat mencari pengetahuan sendiri. Filosofi Ki Hajar Dewantara yang dianut adalah asah, asih, dan asuh (Yus, 2011).

Pendidikan dalam Islam selalu mendasarkan pada konsep dasar manusia (anak) itu sendiri. Anak adalah generasi penerus bangsa. Anak dan masa depan adalah satu kesatuan yang dapat diwujudkan untuk membentuk suatu generasi yang dibutuhkan oleh bangsa terutama bangsa yang sedang membangun (Firman, 2018). Peningkatan keterampilan, pembinaan mental dan moral serta aspek-aspek lainnya harus lebih ditingkatkan. Untuk menghadapi era globalisasi yang ditandai dengan berbagai perubahan tata nilai, anak harus mendapat pembinaan intensif dan terpadu. Dengan demikian, orangtua harus memperhatikan perkembangan jasmani, ruhani, dan akal anak-anaknya (Firman, 2018).

Dalam Bahasa Indonesia, kata "keteladanan" dapat dipahami sebagai perbuatan yang patut untuk ditiru atau dicontoh saja, dalam arti tidak termasuk pada perbuatan yang tidak patut ditiru. Jadi, yang dimaksud dengan keteladanan sebagai uswatun hasanah adalah suatu cara mendidik, membimbing dengan menggunakan contoh yang baik. Oleh karena itu, masalah keteladanan menjadi faktor penting dalam menentukan baik buruknya 
anak. Kepribadian Rasulullah SAW itu merupakan teladan realistis yang telah diletakkan oleh Allah untuk diteladani dalam seluruh aspek ibadahnya, baik yang bersifat qauliyah (perkataan) maupun amaliyah (perbuatan) (Hadhari, 2016). Mendidik dengan memberi keteladanan yaitu dengan memberi keteladanan memiliki dasar sebagaimana yang dijelaskan dalam Al-Qur'an yang menerangkan dasar-dasar pendidikan, antara lain: Pengungkapan kata uswah dalam Al-Qur'an dinyatakan sebanyak tiga kali, yaitu dalam Q.S. AlAhzab/33:21, Q.S. Al-Mumtahanah/60:4 dan Q.S. al-Mumtahanah/60:6. Kata uswah yang terdapat dalam Surat Al-Ahzab menerangkan keteladanan Rasulullah s.a.w., dan dalam Surat Al-Mumtahanah ayat 4 dan 6 menerangkan keteladanan Nabi Ibrahim a.s. Dalam Q.S. Al-Ahzab/33:21 dinyatakan: "Sesungguhnya telah ada pada (diri) Rasulullah itu suri teladan yang baik bagimu (yaitu) bagi orang yang mengharap (rahmat) Allah dan (kedatangan) hari kiamat dan Dia banyak menyebut Allah".

Sedangkan keteladanan dalam Q.S. Al-Mumtahanah/60 ayat 4 yang mengungkapkan keteladanan Nabi Ibrahim adalah sebagai berikut:

"Sesungguhnya telah ada suri tauladan yang baik bagimu pada Ibrahim dan orang-orang yang bersama dengan dia; ketika mereka berkata kepada kaum mereka: "Sesungguhnya kami berlepas diri daripada kamu dari daripada apa yang kamu sembah selain Allah, kami ingkari (kekafiran)mu dan telah nyata antara kami dan kamu permusuhan dan kebencian buat selamalamanya sampai kamu beriman kepada Allah saja. kecuali perkataan Ibrahim kepada bapaknya: "Sesungguhnya aku akan memohonkan ampunan bagi kamu dan aku tiada dapat menolak sesuatupun dari kamu) siksaan (Allah"). Ibrahim berkata: ("Ya Tuhan kami hanya kepada Engkaulah kami bertawakkal dan hanya kepada Engkaulah kami bertaubat dan hanya kepada Engkaulah kami kembali."

Dan dalam Q.S. Al-Mumtahanah/60 ayat 6 artinya:

"Sesungguhnya pada mereka itu (Ibrahim dan umatnya) ada teladan yang baik bagimu; yaitu (bagi orang-orang yang mengharap) pahala (Allah dan) keselamatan pada (hari kemudian. dan barangsiapa yang berpaling, maka sesungguhnya Allah Dia-lah yang Maha Kaya lagi Maha Terpuji".

Berdasarkan uraian di atas diketahui bahwa tauladan juga sangat diperlukan dalam suatu kondisi yang memerlukan pengorbanan, seperti perang, infak, dan lain sebagainya. Rasulullah Saw tampil pula sebagai teladan 
dalam kehidupan suami-istri, dalam kesabaran menghadapi keluarganya, dan dalam mengarahkan istri-istrinya dengan baik. Teladan tersebut akan tetap lestari, selama langit dan bumi ini lestari. Kepribadian Rasulullah Saw sesungguhnya bukan hanya teladan buat suatu masa, generasi, bangsa, golongan atau lingkungan tertentu. Beliau adalah teladan universal buat seluruh manusia dan seluruh generasi. Teladan diartikan sebagai implikasi positif yang kerap terjadi ketika seorang pemimpin berhasil. Kecenderungan yang kerap kita temui adalah keberhasilan acapkali dikaitkan dengan sebuah keteladanan, terlebih patut dij adikan contoh untuk pemimpin selanjutnya.

Keteladanan (uswah hasanah) dijadikan sebagai metode dalam pendidikan Islam secara psikologi didasarkan akan fitrah manusia yang memiliki sifat gharizah (kecenderungan mengimitasi atau meniru orang lain) sehingga Al-Qu'ran memberikan petunjuk pada manusia kepada siapa mereka harus mengikuti agar mereka tidak tersesat. Sehubungan dengan konsep tersebut, dapat dipetik satu pesan tentang keteladanan karena Al-Quran mengenalkan jalan menuju ke sana. Pengaruh keteladanan ini terjadi spontan dan tidak disengaja. Hal ini berarti bahwa setiap orang yang ingin dijadikan panutan oleh orang lain harus senantiasa mengontrol perilakunya dan menyadari bahwa apa yang dilakukannya akan ditiru dan juga dia akan dimintai pertanggungjawaban di hadapan Allah atas segala tindak tanduk yang diikuti oleh khalayak atau ditiru oleh orang-orang yang mengaguminya. Jadi, semakin dia waspada dan tulus untuk berbuat baik, semakin bertambah pula kekaguman orang pada dirinya.

Dalam pendidikan Islam, konsep keteladanan yang dapat dijadikan sebagai cermin dan model dalam pembentukan kepribadian seorang muslim adalah ketauladanan yang dicontohkan oleh Rasulullah Saw. Beliau mampu mengekspresikan kebenaran, kebajikan, kelurusan dan ketinggian pada akhlaknya. Bila ada hal yang menyenangkan beliau hanya tersenyum. Jika menghadapi sesuatu yang menyedihkan, beliau menyembunyikannya serta menahan amarah.

Imam Al-Ghazali menasehati para pendidik agar mengamalkan ilmunya dan tidak mendustakan perkataannya. Disamping itu, sejak kita mengenal agama, kita sudah dianjurkan untuk mencari suri tauladan dalam menjalani kehidupan ini. Ketauladanan itu ada pada diri Rasulullah Saw, sebagaimana terdapat dalam QS. Al-Ahzab: 21.

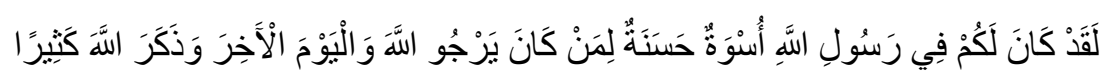

Artinya: Sesungguhnya telah ada pada diri Rasulullah itu suri tauladan yang baik bagimu, yaitu bagi orang- orang yang mengharap rahmat Allah dan kedatangan hari kiamat dan dia banyak menyebut asma Allah (QS. Al-Ahzab: 21). 
Pada ayat ini Allah SWT memperingatkan orang-orang munafik bahwa sebenarnya mereka dapat memperoleh teladan yang baik dari Nabi Saw. Rasulullah Saw adalah seorang yang kuat imannya, berani, sabar, dan tabah menghadapi segala macam cobaan, percaya dengan sepenuhnya kepada segala ketentuan-ketentuan Allah dan beliaupun mempunyai akhlak yang mulia. Jika kaum munafik bercita-cita ingin menjadi manusia yang baik, berbahagia hidup di dunia dan di akhirat, tentulah mereka akan mencontoh dan mengikuti Nabi Saw. Akan tetapi, perbuatan dan tingkah laku mereka menunjukkan bahwa mereka tidak mengharapkan keridhaan Allah dan segala macam bentuk kebahagiaan hakiki itu.

Ada dua tipe peneladanan yang penting, yaitu pengaruh langsung yang tidak disengaja dan pengaruh yang disengaja. Pada tipe yang pertama, pengaruh langsung yang tidak disengaja, keberhasilan tipe peneladanan ini banyak bergantung pada kualitas kesungguhan karakteristik yang dijadikan teladan, seperti keilmuan, kepemimpinan, keikhlasan, dan sebagainya. Dalam kondisi seperti ini, pengaruh teladan berjalan secara langsung tanpa disengaja. Ini berarti bahwa setiap orang yang diharapkan dapat dijadikan teladan untuk memelihara tingkah lakunya. Hal ini disertai kesadaran bahwa ia bertanggung jawab di hadapan Allah dalam segala hal yang diikuti oleh orang lain, terlebih pada para pengagumnya. Dalam hadis yang diriwayatkan dari Ibnu Mas'ud, Rasulullah SAW bersabda: "Barang siapa yang menunjukkan jalan kebaikan, maka ia akan memperoleh pahala sebagaimana pahala yang diterima oleh pelakunya" (H.R. Muslim) (Al-Imam Jalal al-Din, t.th Juz II:11).

Termasuk dalam tipe ini, orang yang diharapkan dapat dijadikan teladan terkadang tidak mengetahui bahwa dirinya menjadi teladan. Dalam hal ini, ia hanya berusaha untuk berperilaku dan bertindak sebagaimana ketentuanketentuan yang telah ditetapkan oleh Allah dan Rasul-Nya, tanpa ada keinginan untuk diikuti orang lain. Dalam kaitan dengan pendidikan formal, pendidik yang baik hanya menjalankan tugasnya yang telah diberikan, atau ia hanya berusaha secara maksimal untuk mematuhi semua ketentuan-ketentuan yang telah ditetapkan oleh sekolah, tanpa ada keinginan untuk dijadikan teladan bagi pendidik yang lain atau peserta didik. Namun, dengan upaya yang ia lakukan secara sungguh-sungguh, menjadikannya sebagai teladan yang akhirnya menjadi panutan bagi lainnya.

Tipe peneladanan yang kedua adalah pengaruh yang sengaja. Dalam hal ini, pengaruh peneladanan terkadang dilakukan dengan sengaja untuk diikuti yang lain. Seorang ustadz memberikan contoh bagaimana membaca AlQur'an dengan baik agar para terdidik menirunya. Di dalam praktek pendidikan dan pengajaran, metode ini dilaksanakan dalam dua cara, yaitu: 1) secara langsung yaitu pendidik harus benar-benar menjadikan dirinya sebagai contoh teladan yang baik kepada peserta didiknya; dan, 2) secara tidak 
langsung yaitu dengan menceritakan kisah-kisah atau riwayat-riwayat orangorang besar, para pahlawan, para syuhada, termasuk para nabi. Dengan mengambil kisah-kisah atau riwayat-riwayat yang demikian itu diharapkan peserta didik akan menjadikan tokoh-tokoh ini sebagai uswatun hasanah.

Kelebihan dan kekurangan metode keteladanan tidak bisa dilihat secara kongkrit, namun secara abstrak dapat diinterpretasikan sebagai berikut. Kelebihan metode keteladanan adalah: a) akan memudahkan anak didik dalam menerapkan ilmu yang dipelajarinya di sekolah; b) akan memudahkan pendidik dalam mengevaluasi hasil belajarnya; c) agar tujuan pendidikan lebih terarah dan tercapai dengan baik; d) bila dalam keteladanan lingkungan sekolah, keluarga dan masyarakat baik, maka akan tercipta situasi yang baik; e) terciptanya hubungan harmonis antara pendidik dan anak didiknya; f) secara tidak langsung pendidik dapat menerapkan ilmu yang diajarkannya; g) mendorong pendidik untuk selalu berbuat baik karena akan dicontoh oleh siswanya. Kekurangan metode keteladanan ini adalah jika figur yang mereka contoh tidak baik, maka mereka cenderung untuk mengikuti tidak baik pula. Jika teori tanpa praktek akan menimbulkan verbalisme.

Pada dasarnya, mufasir juga melihat kebutuhan manusia yang akan menjadi figur teladan bersumber dari kecenderungan meniru yang sudah menjadi karakter manusia. Pada hakikatnya, peniruan itu berpusat pada tiga unsur terhadap orang tuanyanya. Pertama, kesenangan untuk meniru dan mangikuti. Lebih jelasnya hal itu terjadi pada anak-anak dan remaja. Mereka terdorong oleh keinginan yang samar tanpa disadari membawa mereka pada peniruan gaya bicara, cara bergerak, cara bergaul, atau perilaku-perilaku lain dari orang yang mereka kagumi. Kedua, kesiapan untuk meniru. Setiap periode usia manusia memiliki kesiapan dan potensi yang terbatas untuk periode tersebut. Karena itulah, Islam mengenakan kewajiban shalat pada anak yang usianya belum mencapai tujuh tahun dengan tetap menganjurkan kepada orang tua untuk mengajak anaknya meniru gerakan-gerakan shalat. "Sesungguhnya kalian akan mengikuti tradisi orang sebelum kalian, sejengkal demi sejengkal dan sehasta demi sehasta." (Al Hadits). Ketiga, setiap peniruan terkadang memiliki tujuan yang sudah diketahui oleh si peniru atau bisa jadi juga tujuan itu sendiri tidak jelas, bahkan tidak ada. Pada dasarnya, di kalangan anak-anak, peniruan lebih cenderung didorong oleh tujuan yaitu kecenderungan mempertahankan dunia individual karena seolah-olah dia berada di bawah bayang-bayang individu yang kuat dan perkasa, yang membuat orang lemah menirunya.

Anak adalah amanah dari Allah SWT yang harus diemban sebaikbaiknya bagi setiap pribadi yang mengaku dirinya seorang muslim. Anak adalah generasi penerus yang siap melanjutkan estafet perjuangan dan pengemban risalah yang diterima dari Allah SWT sebagai pemakmur bumi sejak awal penciptaan manusia pertama. Untuk itu perlu diupayakan 
pembentukan generasi yang cerdas, berakhlak mulia, dan menjadi anak shaleh karena mereka merupakan deposito jangka panjang untuk orang tuanya di akhirat kelak (Yunus, 2004).

Persoalan pendidikan anak di dalam keluarga adalah persoalan yang sangat banyak dibicarakan. Sebagian orang bahkan beranggapan bahwa pendidikan anak yang paling utama bukan di bangku sekolah, namun justru yang paling penting adalah tahapan pendidikan di dalam keluarga. Namun tidak banyak yang mengetahui bagaimana ajaran Islam mengenai pendidikan anak, khususnya berkenaan dengan cara memberikan pendidikan dalam level usia yang berbeda. Sebab tentu perbedaan usia mempengaruhi pada perbedaan pendekatan dalam melakukan pendidikan pada anak dalam keluarga sebagaimana tuntunan Islam (Abdurrahman \& Rozali, 2019). Dalam hadist yang lain Rasulullah SAW bersabda, "Perintahkanlah anak-anakmu mengerjakan shalat ketika berusia tujuh tahun, dan pukullah mereka jika tidak mau mengerjakannya ketika berusia sepuluh tahun," (HR. Abu Daud, Al Turmuzi, Ahmad dan Al Hakim).

Keluarga merupakan pendidikan pertama dan yang utama bagi anak. Karena dalam keluargalah anak mengawali perkembangannya. Baik itu perkembangan jasmani maupun perkembangan ruhani. Peran keluarga dalam pendidikan bagi anak yang paling utama ialah dalam penanaman sikap dan nilai hidup, pengembangan bakat dan minat, serta pembinaan kepribadian. Adapun yang bertindak sebagai pendidik dalam pendidikan agama dalam keluarga ialah orang tua yaitu ayah dan ibu serta semua orang yang bertanggung jawab terhadap perkembangan anak itu seperti kakek, nenek, paman, bibi dan kakak. Namun yang paling utama ialah ayah dan ibu (Mahmud, 2000).

\section{Metode Penelitian}

Jenis penelitian ini yang digunakan dalam penelitian ini adalah deskriptif dengan penelitian kualitatif. Penelitian deskriptif merupakan penelitian yang dimaksudkan untuk mengumpulkan informasi mengenai status suatu gejala yang ada, yaitu keadaan gejala menurut apa adannya pada saat penelitian dilakukan. Penelitian deskriptif menggambarkan apa adanya tentang sesuatu variabel, gejala atau keadaan (Arikunto, 2000). Penelitian ini menggunakan disain kualitatif karena data yang dihasilakan adalah data deskriptif berupa ucapan atau tulisan dan perilaku partisipan yang diamati (Basrowi, 2008).

Fokus dari penelitian ini adalah keteladanan anak, khususnya santri, di Pondok Pesantren Arriyadl Blimbingsari Kecamatan Sooko Kabupaten Mojokerto. Penelitian ini juga menyelidiki faktor-faktor pendukung dan penghambat dalam fokus penelitian ini. Data diperoleh dengan menggunakan 
tiga teknik yaitu wawancara, observasi, dan dokumentasi. Jenis wawancara yang digunakan peneliti adalah wawancara tidak terstuktur, yaitu wawancara yang pertanyaan-pertanyaannya telah disiapkan, seperti menggunakan pedoman wawancara. Observasi yang digunakan peneliti adalah observasi partipasi moderat (moderate participation). Sedangkan untuk dokumentasi, dokumen yang digunakan dalam penelitian ini yaitu arsip sekolah, buku panduan, buku besar sekolah, dan bahan-bahan statistik lainnya.

Teknik keabsahan data dalam penelitian adalah dengan menggunakan uji kredibilitas (credibility) melalui beberapa cara. Pertama, dengan perpanjangan pengamatan berarti peneliti kembali ke lapangan, melakukan pengamatan, wawancara lagi dengan sumber data yang pernah ditemui maupun yang baru. Dengan perpanjangan pengamatan ini berarti hubungan peneliti dengan nara sumber akan semakin terbentuk, semakin akrab (tidak ada jarak lagi), semakin terbuka, saling mempercayai sehingga tidak ada informasi yang disembunyikan lagi. Kedua, dengan meningkatkan ketekunan berarti melakukan pengamatan secara lebih cermat dan berkesinambungan. Ketiga dengan mengadakan member check. Ini merupakan proses pengecekan data yang diperoleh peneliti dari pemberi data. Tujuan mengadakan member check adalah untuk mengetahui seberapa jauh data yang diperoleh itu sesuai dengan apa yang diberikan oleh pemberi data (Sugiyono, 2010).

\section{Hasil dan Pembahasan}

Dari hasil penelitian yang dilakukan di Pondok Pesantren Arriyadl Blimbingsari Sooko Mojokerto diperoleh beberapa hal. Hasil pengamatan menunjukkan bahwa setiap hari anak-anak yang berangkat dari rumah menuju pondok pesantren akan melihat dan menemui berbagai macam nilai yang berkembang di masyarakat di sepanjang jalan yang mereka lalui. Jika nilai yang ditemui di jalan tidak sesuai dengan nilai yang diajarkan di pondok pesantren maupun di rumah, maka bisa dibayangkan anak akan mengalami kebingungan intelektual yang terus menerus. Akan berbahaya jika apabila anak akhirnya lebih tertarik memilih nilai jalanan ketimbang nilai-nilai yang ditanamkan di pondok pesantren maupun di rumah. Disini peran orang tua dan sekolah sangat penting. Oleh karena itu, orang tua dan ustadz zaman sekarang disamping perlu memiliki karakter yang kuat, harus pula berwawasan luas dan mengikuti perkembangan zaman agar mampu menandingi dan memenangkan pertarungan nilai di hadapan anak-anaknya.

Dari hasil wawancara di Pondok Pesantren Arriyadl diperoleh bahwa kesibukan orang tua di masyarakat dipertontonkan kepada anaknya. Tantangan pendidik saat ini karena kondisi yang kurang mendukung di keluarga. Bagaimana pendidik bisa mengikat dan memikat anak didiknya menjadi insan yang tidak rusak seperti orang tuanya. Persoalan itu belum 
cukup, anak didik sebagai anggota masyarakat juga disuguhi dengan drama perilaku yang tidak kalah buruknya. Ujaran kebencian dan kebohongan menjadi pemandangan yang seringkali ditemui anak pada saat bergaul di masyarakat. Kondisi masyarakat kita longgar dan tidak membawa angin segar bagi pembentukan karakter anak ketika berinteraksi dengan masyarakat.

Begitu juga saat wawancara terhadap ustadz, mereka mengatakan bahwa ustadz yang ada di Pondok Pesantren ArRiyadl juga dilihat dan dipantau tingkah laku dalam keseharian, tata krama dalam berbicara terhadap kyai, teman dan santri-santri yang ada di pondok pesantren, dan semua pola tingkah laku ustadz akan diawasi agar ustadz yang ada di pondok pesantren memiliki ahklak yang baik. Prinsipnya, seorang ustadz harus memiliki kepribadian yang baik.

Dalam berlangsungnya proses pembelajaran di pondok pesantren metode keteladanan dapat diterapkan dalam dua bentuk, yaitu secara langsung dan secara tidak langsung Dalam hal ini dapat dijelaskan bahwa penerapan metode keteladanan dalam proses belajar mengajar dapat dilakukan dengan dua cara yaitu secara langsung maksudnya bahwa pendidik benar-benar mengaktualisasikan dirinya sebagai contoh teladan yang baik bagi anak didik.

Anak merupakan sebuah karunia yang tak ternilai harganya, anak adalah rezeki yang begitu mewah sehingga kita tidak bisa semena-mena, anak adalah titipan dariNya yang wajib kita jaga sekuat tenaga, jutaan orang diluaran sana yang menginginkan memiliki anak, lalu akankah kita masih tidak bersyukur disaat diberikan kesempatan untuk memiliki anak. Anak adalah harapan di masa depan; merekalah kelak yang akan menjadi pengaman dan pelopor masa depan agama dan bangsa. Jadi wajib bagi kita mendidik mereka untuk menjadi generasi tangguh di masa depan. Lebih jauh, Allah memerintahkan kita sebagai orang tua untuk menjauhkan mreeka dari api neraka kelak.

Selain secara langsung, metode keteladanan juga dapat diterapkan secara tidak langsung yang maksudnya, ustadz memberikan teladan kepada santri/anak didiknya dengan cara menceritakan kisah-kisah teladan baik itu yang berupa riwayat para nabi, kisah-kisah orang besar, pahlawan dan syuhada, yang bertujuan agar santri menjadikan tokoh-tokoh tersebut sebagai suri teladan dalam kehidupan mereka. Dari serangkaian pembahasan di atas dapat dikatakan bahwa metode uswah adalah metode pendidikan yang diterapkan dengan cara memberi contoh-contoh (teladan) yang baik yang berupa prilaku nyata, khusunya ibadah dan akhlak. Keteladan merupakan pendidikan yang mengandung nilai pedagogik tinggi bagi peserta didik. Bukankah akhlak yang baik adalah ilmu yang paling tingggi! Hal tersebut senada dengan sabda Rasul Saw: "Sesungguhnya aku diutus untuk menyempurnakan akhlak manusia."

Keteladanan adalah hal-hal yang dapat ditiru atau di contoh oleh seseorang dari orang lain, namun keteladanan yang dimaksud adalah 
keteladanan yang dapat dijadikan alat pendidikan islam yaitu keteladanan yang baik, sesuai dengan pengertian uswah dan ayat al Qur'an. Keteladanan menurut Muchtar, "keteladanan adalah metode pendidikan dengan cara memberikan contoh yang baik kepada peserta didik. Baik dalam ucapan maupun dalam perbuatan (Muchtar, 2005) Adapun metode keteladanan menurut Abdullah Nashih Ulwan (1992) merupakan metode efektif bagi pendidikan anak dan mengasah kreativitas diri seorang pendidik. Selain itu beliau memperkuat pendapatnya dengan argumentasi dari Charles Scaefer keteladanan terdapat isyarat-isyarat non-verbal yang berarti dan menyediakan suatu contoh yang jelas ditiru.

Hal inilah yang perlu mendapatkan perhatian secara akurat sehinggapendidik zaman sekarang tidak berada dalam dua persoalan besar, pertama persoalan yang lahir dari lingkungan keluarga itu sendiri dan persoalan yang terjadi di lingkungan masyarakat. Untuk membantu efektifnya keteladanan yang dicontohkan pendidik agar tertanam dari diri anak didiknya. Pertama, pendidik perlu dibekali dengan karakter yang pilihan bukan karakter rendahan yang tidak berkualitas. Hal ini pendidik menjadi sumber daya manusia yang tegak berdiri di depan kelas. Kedua, orang tua diberikan pembinaan, bisa dari sekolah bekerja sama dengan keluarga untuk memberikan yang terbaik kepada anaknya. Keluarga yang baik inilah yang dapat memberikandukungan penuh pada saat pendidik menanamkan karakter kepada peserta didiknya. Ada jalinan kerja sama dukung-mendukung antara pendidik, keluarga, dan masyarakat. Ketiga, perlu digerakkan program pendidikan kepada masyarakat yang berorientasi penciptaan masyarakat binaan yang ramah anak sekolah. Hal ini akan menciptakan kondisi kehidupan masyarakat yang baik sehingga anak akan meniru perilaku yang baik yang telah ditunjukkan oleh masyarakat.

Dalam memberikan keteladanan dalam proses pendidikan anak, maka sepatutnya pendidik memperhatikan kelebihan dan kekurangan metode pendidikan ini agar dalam penerapannya dijalankan dengan pertimbangan yang baik sehingga orang tua akan sangat berhati-hati dalam memberikan contoh dalam kehidupan sehari-hari. Ada beberapa faktor pendukung keteladanan yaitu faktor genetika (bawaan baik dari orang tua), pengaruh yang baik dari teman, lingkungan yang nyaman dan kondusif, dan mendorong pendidik untuk selalu berbuat baik karena akan dicontoh. Adapun kekurangan metode uswah, diantaranya jika figur yang dicontoh tidak baik, akan cenderung untuk mengikuti tidak baik, pengaruh negatif teman sebaya, bawaan yang buruk dari orang tua, dan pengaruh negatif masyarakat.

Oleh karena itu, orangtua mempunyai peran yang sangat penting dalam membentuk moral kepribadian anak, yaitu melalui pendidikan yang dipraktikkan melalui sikap perbuatan atau teladan dalam kehidupan seharihari. Pendidikan agama dalam keluarga diterapkan dengan keteladanan dan 
hal ini paling meyakinkan keberhasilan dalam membentuk dan mempersiapkan moral, spiritual dan sosial anak". Anak-anak akan meniru perilaku orang dewasa yang mereka amati, jika mereka mendapatkan kedua orang tuanya jujur, maka mereka akan tumbuh menjadi orang jujur. Keteladanan dalam pendidikan adalah merupakan metode aspek moral, spiritual dan etos sosial anak. Hal ini karena pendidik adalah figur terbaik dalam pandangan anak, yang tindaktanduk dan sopan santunnya disadari atau tidak akan ditiru anak.

Dengan demikian keteladanan adalah tindakan atau setiap sesuatu yang dapat ditiru atau diikuti oleh seseorang dari orang lain yang melakukakan atau mewujudkannya, sehingga orang yang diikuti disebut dengan teladan. Namun keteladanan yang dimaksud disini adalah keteladanan yang dapat dijadikan sebagai alat pendidikan Islam, yaitu keteladanan yang baik sehingga dapat disimpulkan bahwa metode keteladanan (uswah) adalah metode pendidikan yang diterapkan dengan cara memberi contoh-contoh (teladan) yang baik yang berupa prilaku nyata, khususnya ibadah dan akhlak.

\section{Kesimpulan}

Berdasarkan penjelasan di atas, dapat disimpulkan bahwa pendidikan Islam terhadap keteladanan adalah suatu tindakan atau setiap sesuatu yang dapat ditiru atau diikuti oleh seseorang dari orang lain yang melakukakan atau mewujudkannya sehingga orang yang diikuti disebut dengan teladan. Namun keteladanan yang dimaksud disini adalah keteladanan yang dapat dijadikan sebagai alat pendidikan Islam, yaitu keteladanan yang baik sehingga dapat didefinisikan bahwa metode keteladanan (uswah) adalah metode pendidikan yang diterapkan dengan cara memberi contoh-contoh (teladan) yang baik yang berupa prilaku nyata, khusunya ibadah dan akhlak. Penelitian ini mengimplikasikan bahwa orang tua perlu berhati-hati dalam memberikan percontohan dala kehidupan sehari-hari. Keteladanan dalam pendidikan Islam adalah merupakan metode aspek moral, spiritual dan etos sosial anak. Hal ini karena pendidik adalah figur terbaik dalam pandangan anak, yang tindaktanduk dan sopan santunnya disadari atau tidak akan ditiru anak.

\section{Daftar Pustaka}

Achmadi. (2005). Ideologi pendidikan Islam: Paradigma humanisme teosentris. Yogyakarta: Pustaka Pelajar.

Akaha, A. Z. (Ed.) (2001). Psikologi anak dan remaja muslim. Jakarta: Pustaka Al-Kautsar. 
Al-Syaibany, O. M. T. (2007). Falsafat pendidikan Islam. (H. Langgulung, Pnjmh). Jakarta: Bulan Bintang. (Karya asli diterbitkan pada 1979).

Al-Suyuthi, Al-Imam Jalal al-Din Abd al-Rahman ibn Abi Bakr. (T. Th). AlJami' al-Shaghir fi Ahadis al-Basyir al-Nadzir, Juz II. Beirut: Dar alFikr.

Arikunto, S. (2000). Manajemen penelitian. Jakarta: Rineka Cipta.

Arisanti, D. (2017). Implementasi pendidikan akhlak mulia di SMA Setia Dharma Pekanbaru. Jurnal Pendidikan Agama Islam Al-Thariqah, 2(2), 206-225. Doi:10.25299/althariqah.2017.vol2(2).1046

Aryani, N. (2015). Konsep pendidikan anak usia dini dalam perspektif pendidikan Islam. Potensia: Jurnal Kependidikan Islam, 1(2), 213-227.

Basrowi, S. (2008). Memahami penelitian kualitatif. Jakarta: Rineka Cipta.

Daradjat., Z. (2006). Ilmu pendidikan Islam. Jakarta: Bumi Aksara.

Firman, A. J. (2018). Studi Al-Qur'an (Teori dan aplikasinya dalam penafsiran ayat pendidikan). Yogyakarta.

Hadhari, A. (2016). Tela'ah atas keteladanan Rasulullah saw dalam mendidik anak. Sumbula: Jurnal Studi Keagamaan, Sosial, dan Budaya, 1(1), 154178.

Hakim, A. A., \& Mubarok, J. (2000). Metodologi studi Islam. Bandung: Remaja Rosdakarya.

Haris, M. (2010). Pendidikan Islam dalam perspektif Prof. H. M. Arifin. Disertasi tidak Dipublikasi. Surabaya: IAIN Sunan Ampel Surabaya.

Hidayat, N. (2015). Metode keteladanan dalam pendidikan Islam. Ta'allum: Jurnal Pendidikan Islam, 3(2), 135-150. Doi:10.21274/taalum.2015.3.2.135-150

Juliadarma, M. (2013). Pencegahan kenakalan anak menurut Abdullah Nasih Ulwan. Disertasi tidak Dipublikasi. Malang: Universitas Muhammadiyah Malang. 
Kholidah, Z. (2018). Relevansi pemikiran Muhammad Iqbal dalam pembentukan karakter siswa di era millenium. Ta'lim: Jurnal Studi Pendidikan Islam, 1(2), 288-308.

Mahmud, A. A. H. (2000). Pendidikan ruhani. Jakarta: Gema Insani.

Mappasiara. (2018). Pendidikan Islam (pengertian, ruang lingkup dan epistemologinya). Jurnal Inspiratif Pendidikan, 7(1), 147-160. Doi:10.24252/ip.v7i1.4940

Muchtar, H. J. (2005). Fikih pendidikan. Bandung: Rosdakarya.

Musrifah. (2017). Pendidikan karakter dalam perspektif Islam. Edukasia Islamika, 1(1), 119-133.

Purnama, S. (2018). Abdullah Nashih 'Ulwan's technological contribution toward the development of Islamic early childhood education. Jurnal Pendidikan Islam, 7(1), 47-77. Doi:10.14421/jpi.2018.71.47-77

Subhan, F. (2013). Memahami pendidikan Islam. Nadwa, 7(1), 141-160. Doi:0.21580/nw.2013.7.1.547

Sugiyono. (2010). Metode penelitian pendidikan pendekatan kuantitatif, kualitatif, $R \& D$. Bandung: Alfabeta.

Tim Penyusun. (1989). Kamus besar bahasa Indonesia Jakarta: Balai Pustaka.

Ulwan, A. N. (1992). Pendidikan anak menurut Islam: Kaidah-kaidah dasar. Bandung: Remaja Rosdakarya.

Yasin, A. F. (2008). Dimensi-dimensi pendidikan Islam. Malang: UIN-Maliki Press.

Yunus, H. S. (2004). Cara mendidik generasi Islami: Sistem dan pola asuh yang Qur'ani. Yogyakarta: Media Jenius Lokal.

Yus, A. (2011). Model pendidikan anak usia dini. Jakarta: Kencana. 